\title{
A Software for Calculating the Economic Aspects of Floating Offshore Renewable Energies
}

\author{
Laura Castro-Santos $1, *(\mathbb{D})$ and Almudena Filgueira-Vizoso ${ }^{2(1)}$ \\ 1 Departamento de Enxeñaría Naval e Industrial, Escola Politécnica Superior, Universidade da Coruña, \\ Esteiro, 15471 Ferrol, Spain \\ 2 Departamento de Química, Escola Politécnica Superior, Universidade da Coruña, Esteiro, 15471 Ferrol, \\ Spain; almudena.filgueira.vizoso@udc.es \\ * Correspondence: laura.castro.santos@udc.es
}

Received: 25 November 2019; Accepted: 24 December 2019; Published: 27 December 2019

\begin{abstract}
The aim of this work is to develop a software to calculate the economic parameters so as to determine the feasibility of a floating offshore renewable farm in a selected location. The software can calculate the economic parameters of several types of offshore renewable energies, as follows: one renewable energy (floating offshore wind-WindFloat, tension leg platform (TLP), and spar; floating wave energy - Pelamis and AquaBuoy), hybrid offshore wind and wave systems (Wave Dragon and W2Power), and combined offshore wind and waves with different systems (independent arrays, peripherally distributed arrays, uniformly distributed arrays, and non-uniformly distributed arrays). The user can select several inputs, such as the location, configuration of the farm, type of floating offshore platform, type of power of the farm, life-cycle of the farm, electric tariff, capital cost, corporate tax, steel cost, percentage of financing, or interest and capacity of the shipyard. The case study is focused on the Galicia region (NW of Spain). The results indicate the economic feasibility of a farm of floating offshore renewable energy in a particular location in terms of its costs, levelized cost of energy (LCOE), internal rate of return (IRR), net present value (NPV), and discounted pay-back period. The tool allows for establishing conclusions about the dependence of the offshore wind resource parameters, the main distances (farm-shore, farm-shipyard, and farm-port), the parameters of the waves, and the bathymetry of the area selected.
\end{abstract}

Keywords: feasibility study; offshore wind; levelized cost of energy (LCOE); wave energy; software

\section{Introduction}

Floating offshore renewable energies are those that are installed in deep waters (more than $50 \mathrm{~m}$ ). They are composed by several main components, namely: energy generators, floating offshore platforms, mooring, anchoring, and electric systems. The main difference between these floating platforms and the fixed platforms (up to $50 \mathrm{~m}$ of depth; monopiles [1], tripiles, jackets [2], etc.) [3] is that these last ones have platforms fixed to the seabed using several devices; therefore, they do not have mooring and anchoring systems.

In this context, the most developed technology is offshore wind systems, although wave energy will have great development in the future too. Floating offshore wind energy has been developed over the last years, mainly in Europe and Japan $[4,5]$. Hywind Scotland was the first commercial floating offshore wind farm installed in the world. It was installed in 2017 in Scottish waters [6] by Statoil. It is based on a spar floating platform called Hywind, which was previously probed in Norway in 2009 [7]. It has five spar platforms that were built in the Navantia-Fene shipyard in Fene (A Coruña, Spain). This shipyard is the leader in floating offshore wind building-it built one platform for the WindFloat Atlantic project (Windplus) in Portugal in 2019 (the first floating offshore wind farm in the Iberia 
Peninsula [8]), and it is starting to build five platforms for the Kinkardine project (Aberdeen, U.K.), consisting of $9.5 \mathrm{MW}$ platforms [9].

Floating offshore renewable energies will have a great future. However, nowadays, they are still in development, mainly wave energy systems and hybrid technology, and need to increase their unitary power in order to be more competitive with conventional offshore wind. Therefore, it is important to determine the best areas where a floating offshore renewable energy farm can be installed, and calculate their economic feasibility in order to make decisions about the final installation of these technologies. There are some studies about the types of restrictions of the areas where offshore wind energy is installed [10], restrictions for wave energy [11], mapping the electric system of offshore ports [12], and a comparison between onshore and offshore wind [7].

There is a lot of information about offshore platforms, namely: semisubmersible [13-15], tensioned leg platform (TLP) [16,17], and spar [18]. Arapogianni [19] analysed the main floating systems and differences between the grid connected systems (Hywind of Statoil and WindFloat of Principle Power) and the concepts under development (Advanced Floating Turbine of Nautica WindPower; Aero-generator X of Wind Power Ltd. Arup, Azimut of Consortium of Spanish Wind Energy Industry lead by Gamesa; Blue H TLP of Blue H; DeepCWind floating wind of the consortium of the University of Maine, AEWC, Seawall, Maine Maritime Academy, Technip, NREL and MARIN; Deepwind, which is an EU project; DIWET Semisub of Pole Mer; EOLIA of Acciona Energy; IDEOL of IDEOL; GICON TLP of GICON; Hexicon platform of Hexicon; HiPRwind, an EU project; Karmoy of Sway; Ocean Breeze of Xanthus Energy; W2Power of Pelagic Power; Pelastar of Glosten Associates; Poseidon Floating Power of the Floating Power; Sea Twirl of Sea Twirl; Trifloater Semisub of Gusto; Vertiwind of Technip and Nenuphar; WindSea Floater of Force technology NLI; Winflo of Nass and Wind and DCNS; ZEFIR Test Station of Catalonia Institute for Energy Research; and Haliade of Alstom). Perhaps the most representative is the research developed by Jonkman and Matha [19,20], where a spar, a semisubmersible, and a TLP (tensioned leg platform) were calculated, because it compares the three main types of floating offshore wind platforms. In this context, Sclavounos et al. [21,22] also considered the taught leg buoy concept. Collu et al. compared fixed and floating structures for a 5-MW wind turbine [23].

However, all of these studies did not take into account the economic aspects of such technologies, although Wind Europe has established the importance of cost reductions [24] in order to create competitive technologies comparable with onshore renewable energies. In addition, presently, there is not any software that allows the user to develop the economic calculation of the offshore renewable energy of several choices (wind, waves, and wind and waves), which is the objective of the present work.

The aim of this paper is to create a software to calculate the most important parameters of the economic feasibility of a floating offshore renewable farm in a selected location.

\section{Software Characteristics}

\subsection{Description of the Software}

The software can calculate the economic parameters of several types of offshore renewable energies, as follows: one renewable energy (floating offshore wind-WindFloat, TLP, and spar; floating wave energy - Pelamis [25] and AquaBuoy [26]), hybrid offshore wind and wave systems (Wave Dragon [27] and W2Power [28]), and combined offshore wind and waves with different systems (independent arrays, peripherally distributed arrays, uniformly distributed arrays, and non-uniformly distributed arrays). The user can select several inputs, namely: location, configuration of the farm, type of floating offshore platform, type of calculation of the wave's energy, power of the farm, life-cycle of the farm, electric tariff, capital cost, corporate tax, steel cost, percentage of financing, interest, and capacity of the shipyard. The case study is focused on the Galicia region, located in the North-West of Spain. The economic results are as follows: the cost of each phase of the life-cycle of the project, the total cost of the life-cycle of the farm, the internal rate of return (IRR), the net present value (NPV), the 
discounted payback period (DPBP), and the levelized cost of energy (LCOE). The results indicate the economic feasibility of a farm of floating offshore renewable energy in a particular location.

The objective of the created software (W2EC by LCS "Wind and Wave Energy farm economic Calculator" by Laura Castro Santos) is to calculate several economic parameters of a floating offshore renewable energy farm in a location. The formulation of costs has been previously developed [28]. This software has been created for the locations of Galicia, the Galicia and Cantabric region, and Portugal, because these are the input maps data that we have available. However, if the data of other locations is obtained, new areas of analysis can be included. Therefore, the software can be used for any location that the user wants. The software has been registered.

The user can select the inputs wanted in order to calculate the economic maps of the location selected. The programming language is MATLAB $($ (MathWorks, Natick, MA, USA), and the software is compatible with Microsoft Windows $®(M i c r o s o f t$, Redmond, WA, USA).

Firstly, the software calculates the main costs of the life-cycle of the offshore renewable energy farm (definition of the concept, design and development, manufacturing, installation [13], exploitation, and dismantling), and then the total life-cycle cost of the farm is calculated $[29,30]$. The novelty of this work is to develop a software using an easy interface and considering several types of offshore renewable energies. Therefore, the calculation of the costs will be conditioned by the type of energy selected, among other factors.

In addition, the map inputs (scale parameter of the offshore wind resource, shape parameter of the offshore wind resource, distance from farm to shore, distance from farm to shipyard, distance from farm to port, height of waves, period of waves, and bathymetry) generate a map of the energy produced in the specific location selected.

\subsection{Inputs of the Software}

In this context, the inputs of the software are (see Tables 1 and 2 and Figure 1):

Table 1. Inputs of the software I. TLP- tensioned leg platform.

\begin{tabular}{cc}
\hline Input & Types \\
\hline Location & Galicia \\
& Galicia and Cantabric region \\
Portugal
\end{tabular}


Figure 2 shows the input variables (location, configuration of the farm, floating platform, calculation of energy waves, total power of the farm (Ptotalfarm), number of years of the life-cycle (Nfarm), electric tariff, corporate tax, \% financing, \% interest, capital cost, cost of steel (Csteel), and number platforms per year) that are used to calculate the total cost of the farm (Ctotal) and the input maps related to the selected location (shape and scale of the wind parameter, bathymetry, and period and height of waves), whose value is different depending on the point $(\mathrm{k})$ of the defined grid.

Table 2. Inputs of the software II.

\begin{tabular}{c}
\hline Inputs \\
\hline Power of the farm $(\mathrm{MW})$ \\
Life-cycle of the farm (years) \\
Electric tariff $(€ / \mathrm{MWh})$ \\
Capital cost $(\%)$ \\
Corporate tax $(\%)$ \\
Steel cost $(€ /$ ton) \\
Percentage of Financing $(\%)$ \\
Interest $(\%)$ \\
Capacity of the shipyard (platform/year) \\
\hline
\end{tabular}

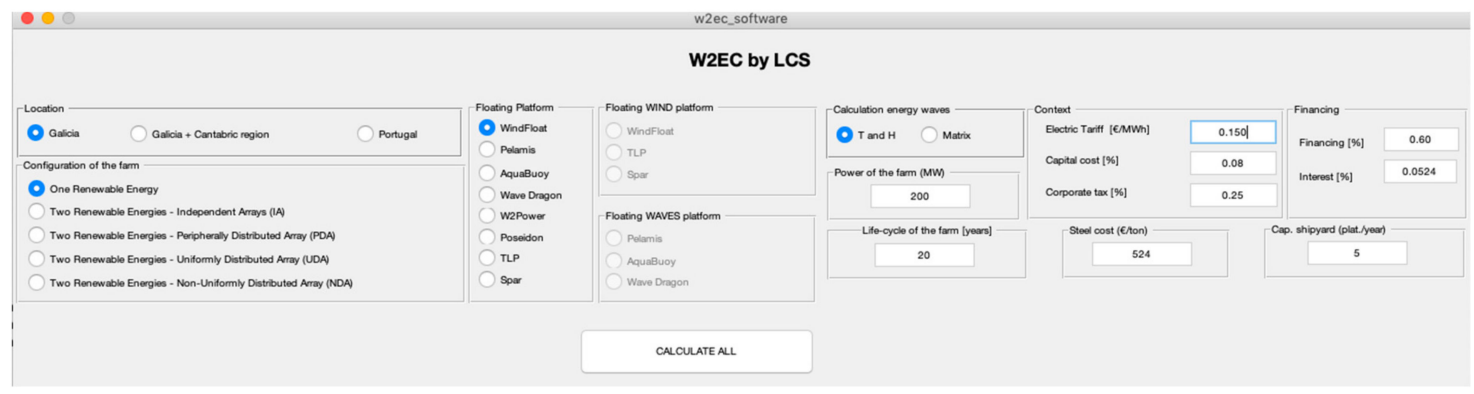

Figure 1. Software interface.

The software calculates the economic parameters of the project, considering the energy produced and the total life-cycle cost such as input variables. The economic results obtained are as follows:

Internal rate of return of the financed project (IRR FP; \%).

Net present value of the financed project (NPV FP; M€).

Discounted payback period of the financed project (DPBP FP; years).

Levelized cost of energy (LCOE; $€ / \mathrm{MWh}$ ). 


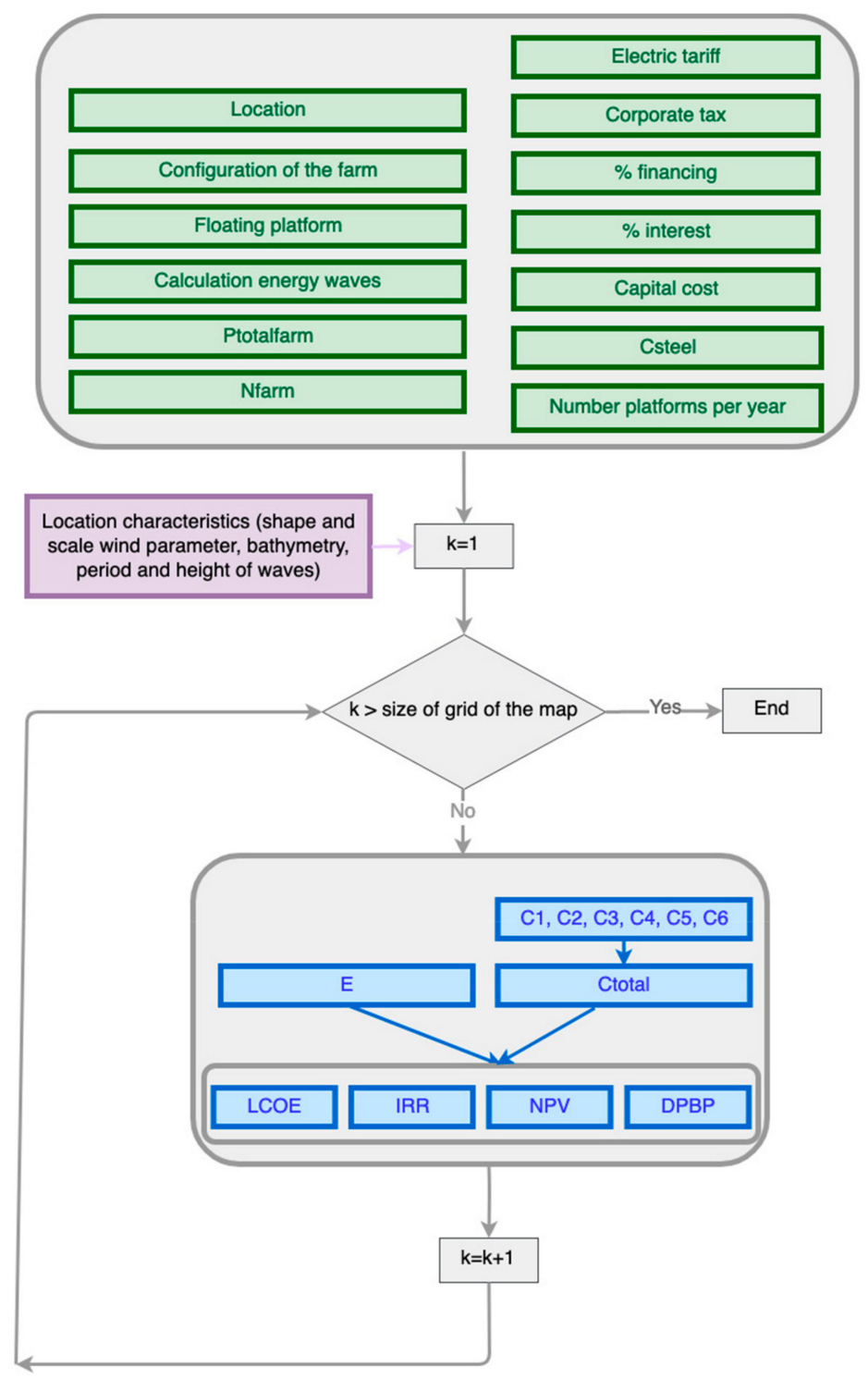

Figure 2. Flow diagram of the software. Input variables being the following: the total power of the farm (Ptotalfarm), number of years of the life-cycle (Nfarm), cost of steel (Csteel), the number of points that the input maps have (k), energy produced (E), total cost of the farm (Ctotal), defining cost (C1), designing and developing cost (C2), manufacturing cost (C3), installing cost (C4), exploiting cost (C5), and dismantling cost (C6).

\subsection{Criteria and Protocol}

Regarding the location, the user selects this input and he has three options (Galicia, Galicia + Cantabric region and Portugal). These choices condition the map files (in .mat) that the software selects for acting related to scale parameter of the offshore wind resource (Figure 3a), shape parameter of the offshore wind resource (Figure $3 b$ ), distance from farm to shore (Figure 3c), distance from farm to shipyard (Figure 3d), distance from farm to port (Figure 3e), height of waves (Figure 3f), period of waves (Figure $3 \mathrm{~g}$ ) and bathymetry (Figure 3h).

Regarding the type of floating platform, the criteria is that they are divided in wind (WindFloat [31], spar [21] and TLP (Tensioned Leg Platform) [21]), waves (Pelamis [25], AquaBuoy [32] and Wave Dragon [33]) or hybrid (W2Power [28] and Poseidon [34]) (see Figure 4). Depending on the type of platform selected, the protocol to calculate the cost of manufacturing the platform, its generator, 
its mooring and its anchoring, will change. In addition, it also affects to the installation, maintenance and decommissioning cost.

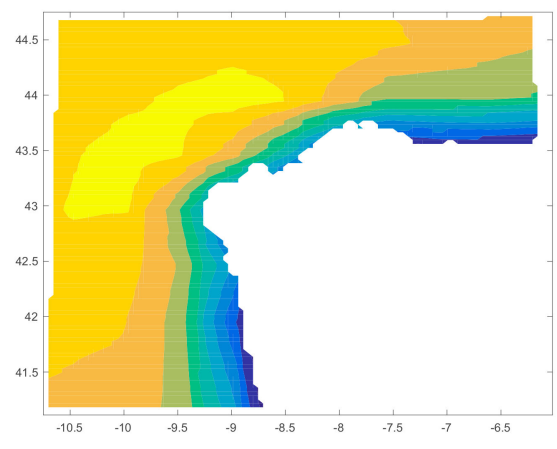

(a)

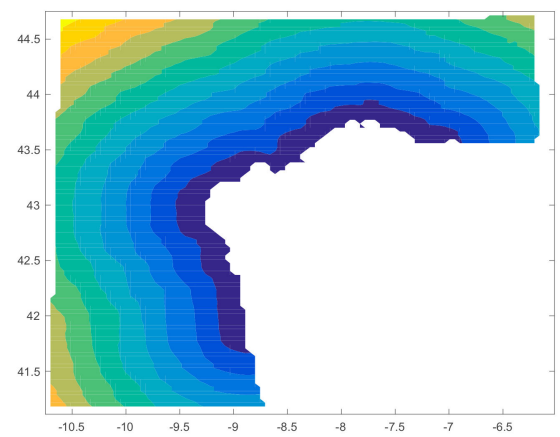

(c)

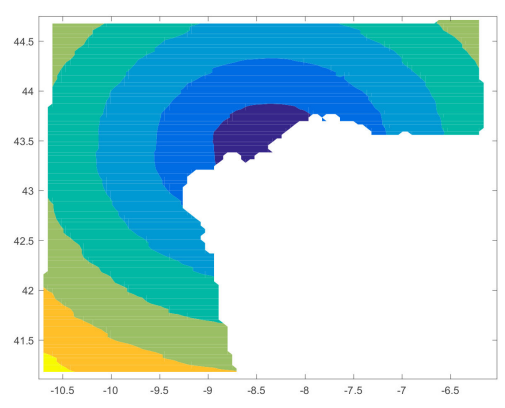

(e)

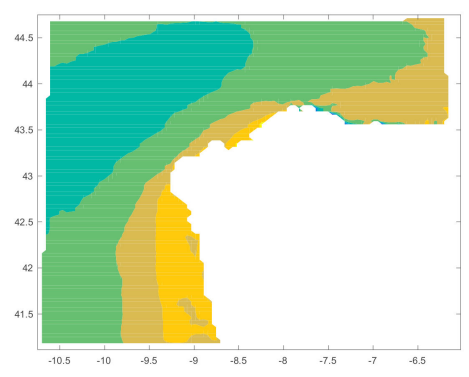

(g)

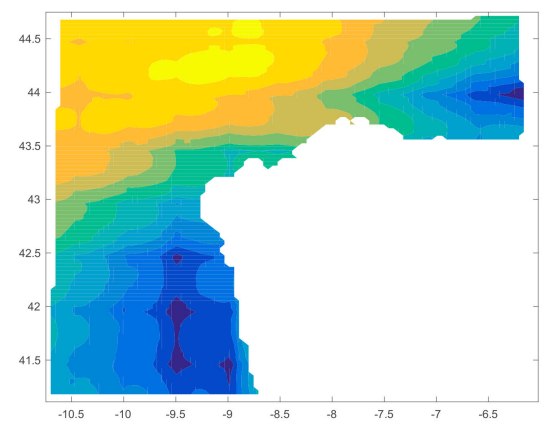

(b)

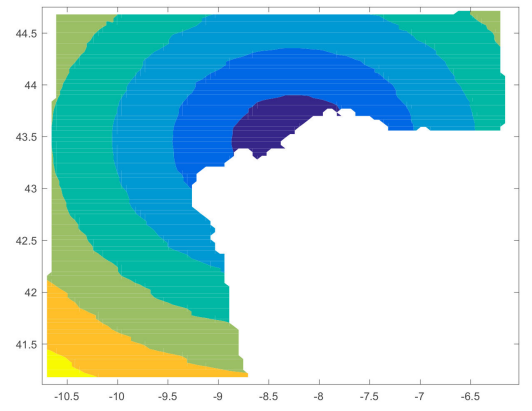

(d)

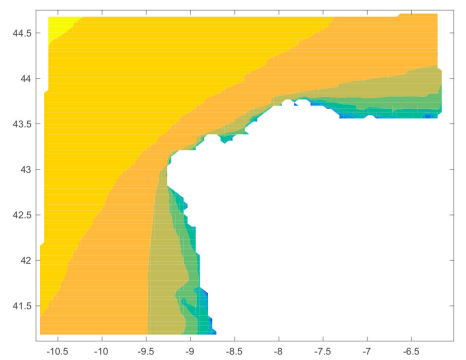

(f)

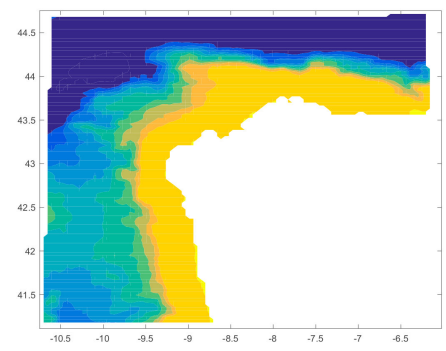

(h)

Figure 3. Map inputs: scale parameter of the offshore wind resource (a) in $\mathrm{m} / \mathrm{s}$, shape parameter of the offshore wind resource (b), distance from farm to shore in $\mathrm{m}(\mathbf{c})$, distance from farm to shipyard in $\mathrm{m}(\mathbf{d})$, distance from farm to port in $\mathrm{m}(\mathbf{e})$, height of waves in $\mathrm{m}(\mathbf{f})$, period of waves in $\mathrm{s}(\mathrm{g})$, and bathymetry in $\mathrm{m}(\mathbf{h})$. 


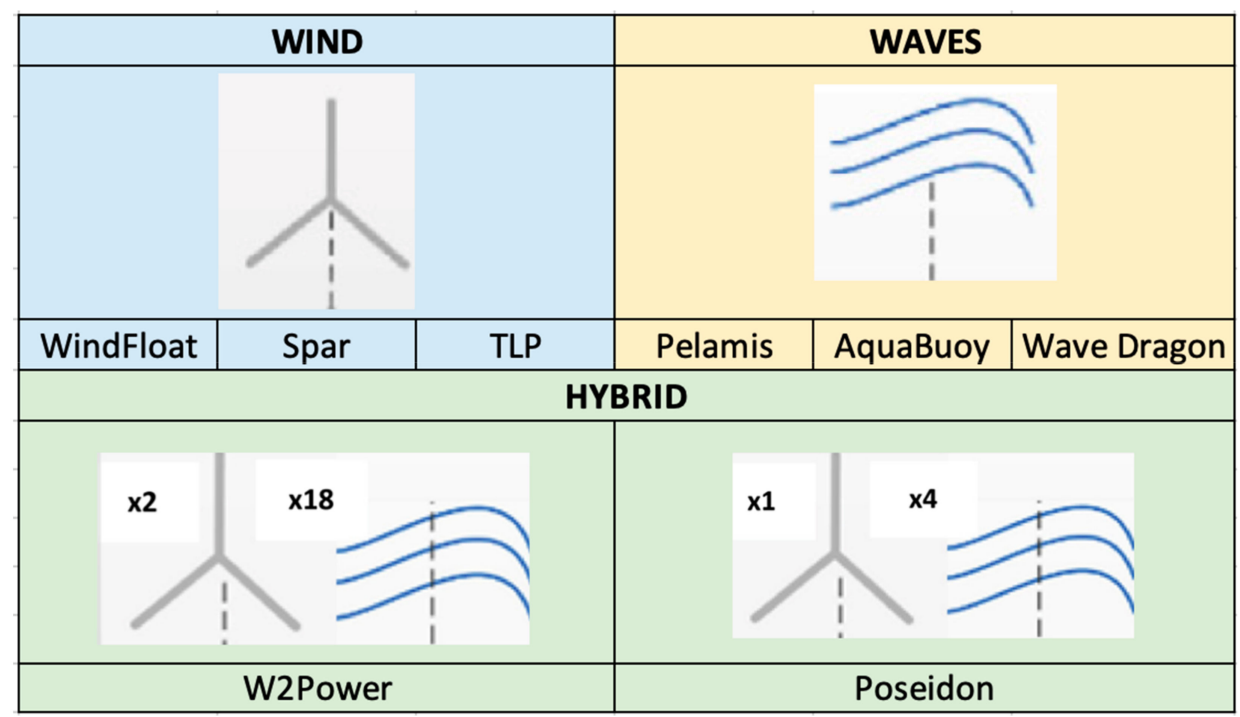

Figure 4. Type of floating platform inputs: wind (WindFlaot, spar, TLP), waves (Pelamis, AquaBuoy, Wave Dragon) and Hybrid (W2Power, Poseidon).

Regarding the configuration of the farm figure shows the four types of inputs: one renewable energy (Figure 5a), two renewable energies and independent arrays (Figure 5b), two renewable energies and peripherally distributed array. Figure $5 \mathrm{c}$ two renewable energies and uniformly distributed array (Figure $5 \mathrm{~d}$ ) and two renewable energies and non-uniformly distributed array (Figure 5e). They will condition the length, type and size of the electric cable between platforms, which has a great influence on costs.

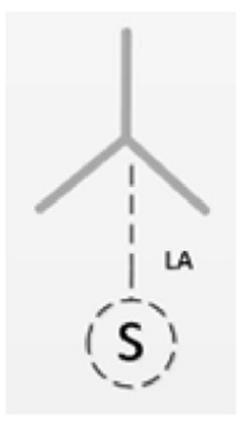

(a)

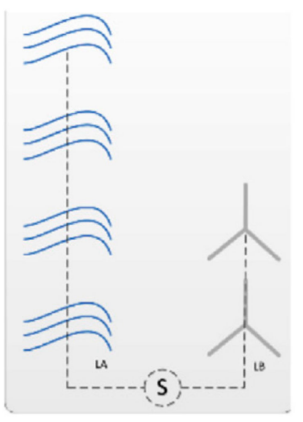

(b)

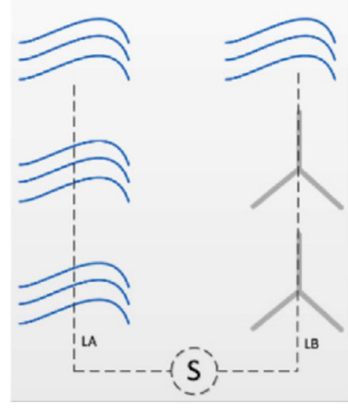

(c)

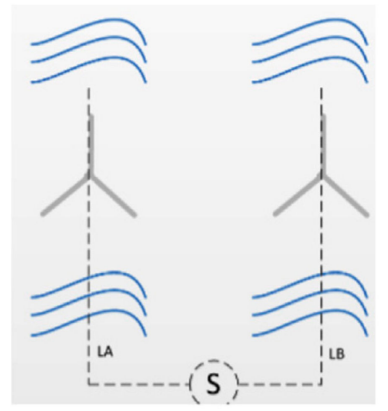

(d)

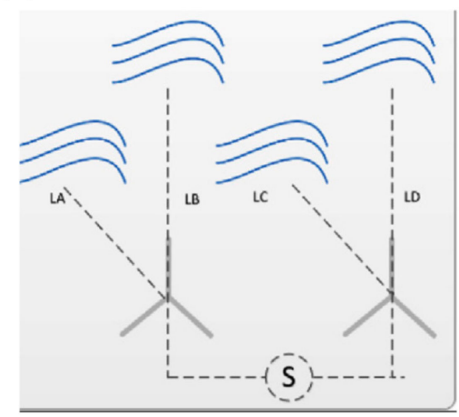

(e)

Figure 5. Configuration of the farm inputs [35]: one renewable energy (a), two renewable energies and independent arrays (b), two renewable energies and peripherally distributed arrays (c), two renewable energies and uniformly distributed arrays (d), and two renewable energies and non-uniformly distributed arrays (e). 
Considering the type of calculation of the wave's energy, there are two main types, namely: $\mathrm{T}$ and $\mathrm{H}$ (period and height of waves, respectively), and matrix. The first consideration takes into account a general equation for the calculation of the energy generated by a wave energy converter considering the period of waves $\left(T_{w a}\right)$, the height of waves $\left(H_{w a}\right)$, the number of hours per year (NHAT), the density of water $(\rho)$, the gravity $(g)$, the main dimension $\left(D_{\text {wa }}\right)$, and the efficiency of the wave generator $\left(\eta_{\text {effiency }}\right)$. This equation is used when there is not enough information of the area selected to create the matrix (see Equation (1) [35]). Therefore, this calculation is an approximation to the real value of the energy produced by the wave farm.

$$
E_{1 w a}=N H A T \cdot \frac{2}{64} \cdot \frac{\rho \cdot g^{2}}{\pi} \cdot T_{w a} \cdot H_{w a}^{2} \cdot D_{w a} \cdot \eta_{e f f i e n c y}
$$

The second type considers the power matrix of the technology. Table 3 shows an example of the power matrix of the Pelamis wave energy converter) and the matrix of the location, which is more difficult to obtain.

Table 3. Pelamis power matrix (in kW) [36].

\begin{tabular}{|c|c|c|c|c|c|c|c|c|c|c|c|c|c|c|c|c|c|}
\hline \multirow{2}{*}{$\mathrm{Te}(\mathrm{s}) \mathrm{Hs}(\mathrm{m})$} & \multicolumn{17}{|c|}{ Power Matrix (in kW) } \\
\hline & 5 & 5.5 & 6 & 6.5 & 7 & 7.5 & 8 & 8.5 & 9 & 9.5 & 10 & 10.5 & 511 & 11.5 & 12 & 12.5 & 13 \\
\hline 0.5 & 0 & 0 & 0 & 0 & 0 & 0 & 0 & 0 & 0 & 0 & 0 & 0 & 0 & 0 & 0 & 0 & 0 \\
\hline 1 & 0 & 22 & 29 & 34 & 37 & 38 & 38 & 37 & 35 & 32 & 29 & 26 & 23 & 21 & 0 & 0 & 0 \\
\hline 1.5 & 32 & 50 & 65 & 76 & 83 & 86 & 86 & 83 & 78 & 72 & 65 & 59 & 53 & 47 & 42 & 37 & 33 \\
\hline 2 & 57 & 88 & 115 & 136 & 148 & 153 & 152 & 147 & 138 & 127 & 116 & 104 & 93 & 83 & 74 & 66 & 59 \\
\hline 2.5 & 89 & 138 & 180 & 212 & 231 & 238 & 238 & 230 & 216 & 199 & 181 & 163 & 146 & 130 & 116 & 103 & 92 \\
\hline 3 & 129 & 198 & 260 & 305 & 332 & 240 & 332 & 315 & 292 & 266 & 240 & 219 & 210 & 188 & 167 & 149 & 132 \\
\hline 3.5 & 0 & 270 & 345 & 415 & 438 & 440 & 424 & 404 & 377 & 362 & 326 & 292 & 260 & 230 & 215 & 202 & 180 \\
\hline 4 & 0 & 0 & 462 & 502 & 540 & 546 & 530 & 499 & 475 & 429 & 384 & 366 & 339 & 301 & 267 & 237 & 213 \\
\hline 4.5 & 0 & 0 & 544 & 635 & 642 & 648 & 628 & 590 & 562 & 528 & 473 & 432 & 382 & 356 & 338 & 300 & 266 \\
\hline 5 & 0 & 0 & 0 & 739 & 726 & 726 & 707 & 687 & 670 & 607 & 557 & 521 & 472 & 417 & 369 & 348 & 328 \\
\hline 5.5 & 0 & 0 & 0 & 750 & 750 & 750 & 750 & 750 & 737 & 667 & 658 & 586 & 530 & 496 & 446 & 395 & 355 \\
\hline 6 & 0 & 0 & 0 & 0 & 750 & 750 & 750 & 750 & 750 & 750 & 711 & 633 & 619 & 558 & 512 & 470 & 415 \\
\hline 6.5 & 0 & 0 & 0 & 0 & 750 & 750 & 750 & 750 & 750 & 750 & 750 & 743 & 658 & 621 & 579 & 512 & 481 \\
\hline 7 & 0 & 0 & 0 & 0 & 0 & 750 & 750 & 750 & 750 & 750 & 750 & 750 & 750 & 676 & 613 & 584 & 525 \\
\hline 7.5 & 0 & 0 & 0 & 0 & 0 & 0 & 750 & 750 & 750 & 750 & 750 & 750 & 750 & 750 & 686 & 622 & 593 \\
\hline 8 & 0 & 0 & 0 & 0 & 0 & 0 & 0 & 750 & 750 & 750 & 750 & 750 & 750 & 750 & 750 & 690 & 625 \\
\hline
\end{tabular}

On the other side, the power farm and the life-cycle of the farm are introduced by the user, depending on his needs. The electric tariff, capital cost, corporate tax, and steel cost are values that depend on the market being analyzed. The percentage of financing and the interest are determined by the financing company. Finally, the capacity of the shipyard depends on the shipyard where the platforms were built, mainly its size, and works in development in the moment of building the platforms.

Finally, considering the outputs, the equations used are shown in Table 4, as follows [36-38]: C1, in $€$, is the defining cost; $C 2$ in $€$ is the designing and developing cost; $C 3$, in $€$, is the manufacturing cost; $C 4$, in $€$, is the installing cost; $C 5$, in $€$, is the exploiting cost; $C 6$, in $€$, is the dismantling cost, $C_{t}$, in $€$, is the cost of the correspondent year, $E_{t}$, in MWh/year, is the energy produced, $r$, in \%, is the capital cost; $C F_{t}$ is the cash flow; $t$, in years, is the life-cycle of the project; and $G_{0}$, in $€$, is the initial investment. The project will be economically feasible if the net present value is positive, the internal rate of return is higher than the capital cost, and the levelized cost of energy has low values. 
Table 4. Output criteria.

\begin{tabular}{cc}
\hline Output & Equation \\
\hline Total cost & $C_{\text {total }}=C 1+C 2+C 3+C 4+C 5+C 6$ \\
Levelized cost of energy & $L C O E=\frac{\sum_{t=0}^{N_{\text {farm }}} \frac{C_{t}}{(1+r)^{t}}}{\sum_{t=0}^{N_{\text {farm }}} \frac{E_{t}}{(1+r)^{t}}}$ \\
Net present value & $N P V=-G_{0}+\sum_{t=1}^{n} \frac{C F_{t}}{(1+r)^{t}}$ \\
Internal rate of return & $-G_{0}+\sum_{t=1}^{n} \frac{C F_{t}}{(1+I R R)^{t}}=0$ \\
\hline
\end{tabular}

\section{Case of Study and Results}

\subsection{Case of Study}

The case of study of the present paper is the Galician region, located in the North-West of Spain (in red in Figure 6), which has very good conditions in terms of offshore wind and offshore wave resources.

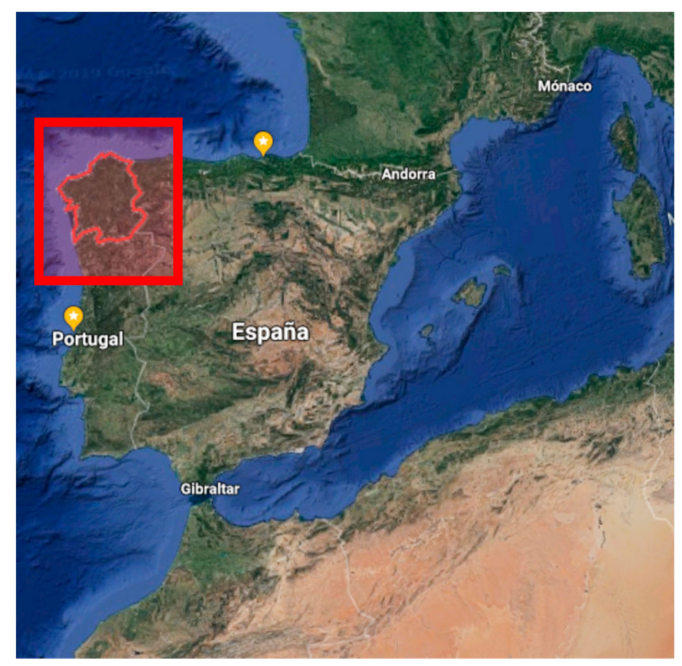

Figure 6. Galicia region (NW of Spain), in red.

The four cases studied in this paper differ, depending on their type of floating offshore renewable energy platforms (Table 5), as follows: wind platform (WindFloat) [16,39] in Case 1, wind platform (WindFloat) and wave platform (AquaBuoy) in Case 2, wave platform (AquaBuoy) [26] in Case 3, and a hybrid platform that mixes wind and wave energy in the same platform (W2Power [28]) in Case 4.

Table 5. Characteristics of the case studies.

\begin{tabular}{|c|c|c|c|c|}
\hline Input & Case of Study 1 & Case of Study 2 & Case of Study 3 & Case of Study 4 \\
\hline Location & Galicia & Galicia & Galicia & Galicia \\
\hline $\begin{array}{l}\text { Configuration of the } \\
\text { farm }\end{array}$ & $\begin{array}{l}\text { One Renewable } \\
\text { Energy }\end{array}$ & $\begin{array}{c}\text { Two Renewable } \\
\text { Energies-Independent } \\
\text { Arrays (IA) }\end{array}$ & $\begin{array}{l}\text { One Renewable } \\
\text { Energy }\end{array}$ & $\begin{array}{c}\text { One Renewable } \\
\text { Energy }\end{array}$ \\
\hline Floating platform & WindFloat & $\begin{array}{l}\text { WindFloat } \\
\text { and } \\
\text { AquaBuoy }\end{array}$ & AquaBuoy & W2Power \\
\hline $\begin{array}{c}\text { Calculation energy } \\
\text { waves }\end{array}$ & - & $\mathrm{T}$ and $\mathrm{H}$ & $\mathrm{T}$ and $\mathrm{H}$ & $\mathrm{T}$ and $\mathrm{H}$ \\
\hline
\end{tabular}

For the case study of this paper, the inputs of the four cases of study are shown in Table 6. 
Table 6. Inputs.

\begin{tabular}{ccc}
\hline Input & Value & Units \\
\hline Power of the farm & 200 & MW \\
Life-cycle of the farm & 20 & years \\
Electric tariff & 150 & $€ / \mathrm{MWh}$ \\
Capital cost & $8 \%$ & - \\
Corporate tax & $25 \%$ & - \\
Steel cost & 524 & $€ /$ ton \\
Percentage of financing & $60 \%$ & - \\
Interest & $5.24 \%$ & - \\
Capacity of the shipyard & 5 & Platforms/year \\
\hline
\end{tabular}

\subsection{Results}

The software created calculates the energy produced by a floating offshore renewable energy farm. In the particular cases of study of this paper, the energy produced by a floating offshore renewable energy farm composed by offshore wind turbines (Figure 7a), offshore wind and waves (different platforms) (Figure 7b), offshore wave energy (Figure 7c) and offshore hybrid platform (wind and waves in the same platform) (Figure 7d), has different values depending on the type of technology selected. The values go from 79,500,000 MWh/year to 701,000,000 M€/year for case 1; from 58,890,000 MWh/year to 497,340,000 M€/year for case 2; from 7,087,500 MWh/year to 121,110,000 $\mathrm{M€} /$ year for case 3; and from 37,843,000 MWh/year to 312,220,000 M€/year for case 4.

On the other hand, the software gives results regarding the costs $(\mathrm{C} 1, \mathrm{C} 2, \mathrm{C} 3, \mathrm{C} 4, \mathrm{C} 5, \mathrm{C} 6$, and Ctotal) and the economic feasibility of the floating offshore renewable energy farm (LCOE, IRR, NPV, and DPBP).

Figures $8-11$ are the maps of results for case 1 , case 2, case 3 and case 4 respectively. It is important to notice that results of all the maps depend on the shape and scale parameters of the offshore wind resource, the distance from farm to shore, distance from farm to shipyard, distance from farm to port, the height and the period of waves and the bathymetry of the location of study (in this case the Galician region). This fact is shown in Figures 8-11. Of course, the maps of results depend on the inputs, therefore this software is valid for all the locations that user wants.

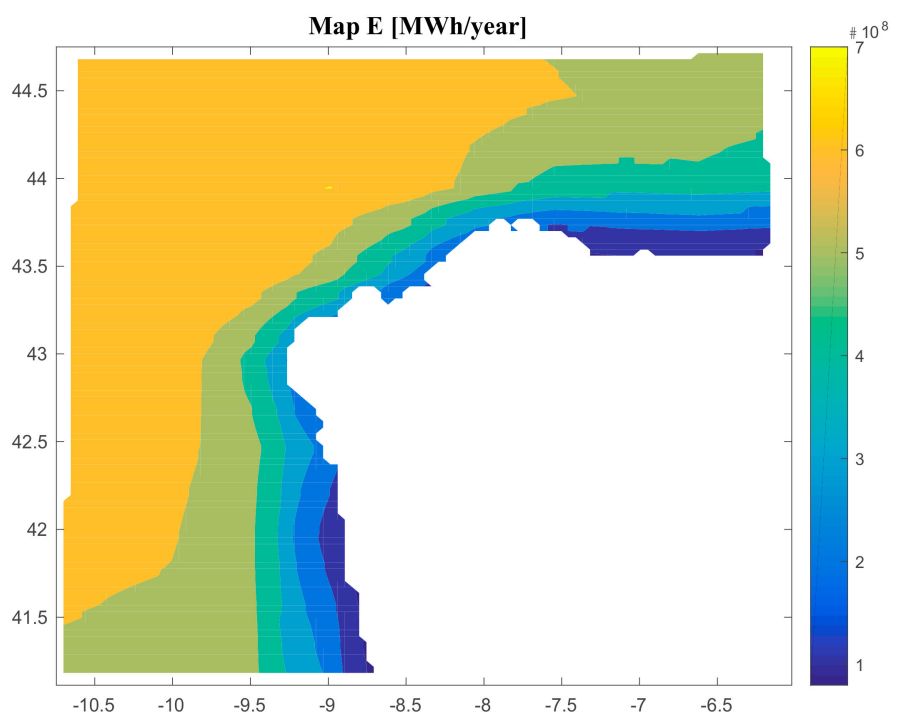

(a)

Figure 7. Cont. 


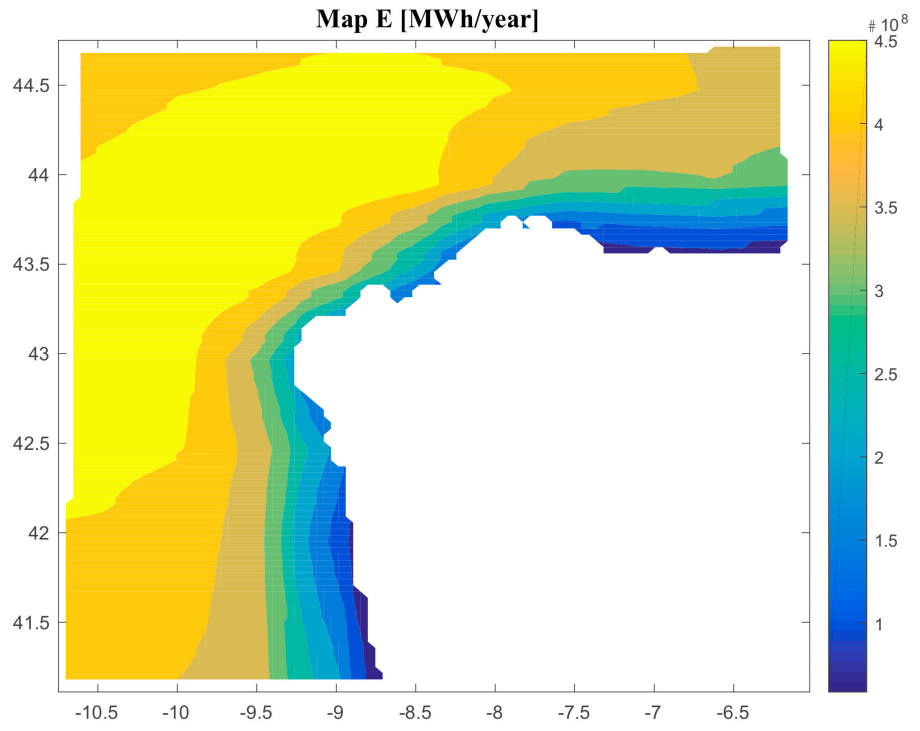

(b)

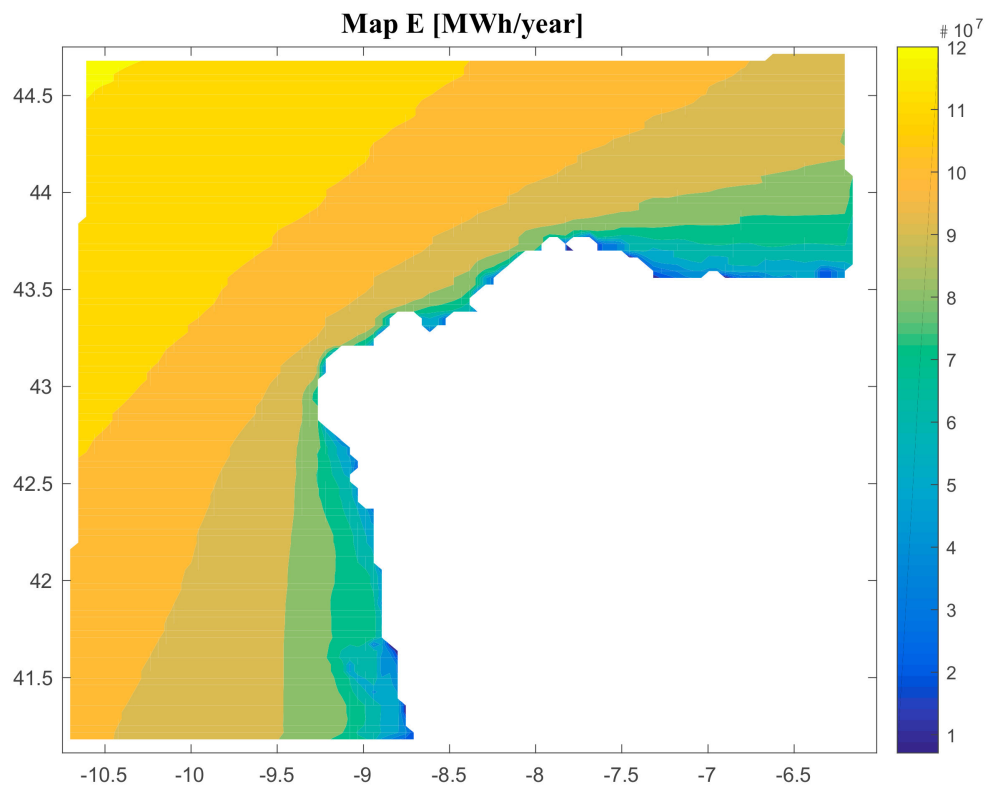

(c)

Figure 7. Cont. 


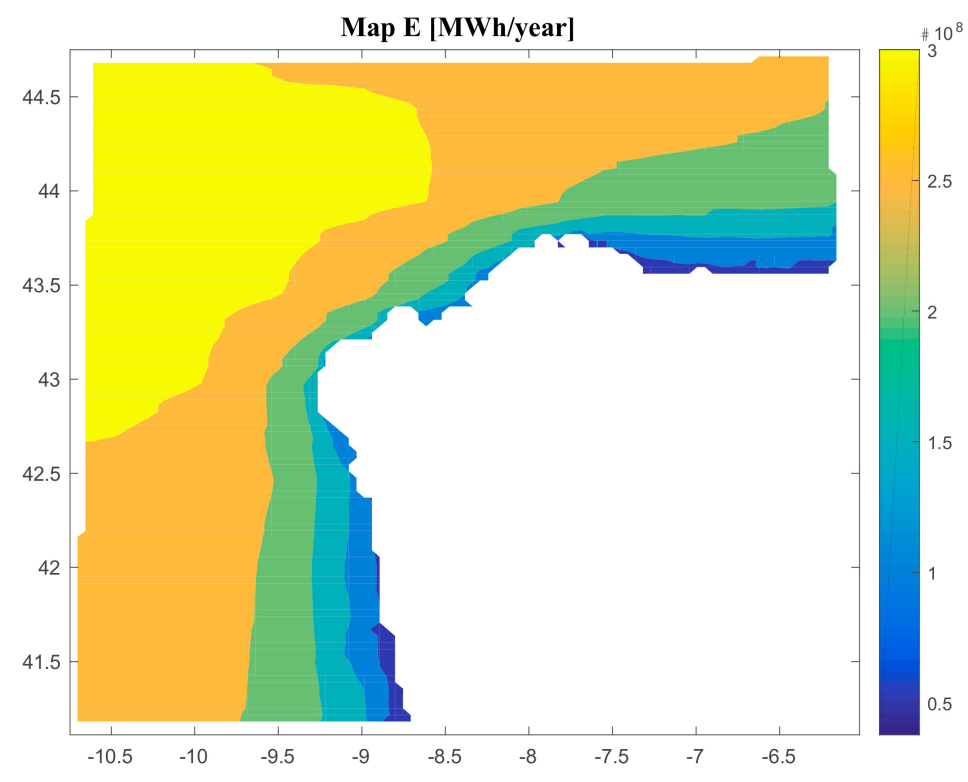

(d)

Figure 7. Results of the energy produced for Case 1 (a); Results of the energy produced for Case 2 (b); Results of the energy produced for Case 3 (c); Results of the energy produced for Case 4 (d).

Regarding case 1, results depends on the location and they go (see Figure 8): from 6.94 M€ to 126.52 M€ for C1; 0.46 M€ for C2; from 403.02 M€ to 847.23 M€ for C3; from 14.85 M€ to 272.11 M€ for C4; from 241.68 M€ to 409.15 M€ for C5; from 1.44 M€ to 37.23 M€ for C6; from 674.21 M€ to 1650 M€ for Ctotal; from 100.31 €/MWh to 882.93€/MWh for LCOE; from 11 years to 22 years for DPBP; from $-142.40 \%$ to $14.75 \%$ for IRR; and from $-535.50 €$ to $330.85 €$ for NPV.

Regarding Case 2, the results depend on the location, and they go (see Figure 9) from $4.85 \mathrm{M} €$ to 503.08 M€ for C1, 0.34 M€ for C2, from 367.45 M€ to 676.09 M€ for C3, from 9.92 M€ to 180.32 M€ for C4, from 314.59 M€ to 482.57 M€ for C5, from 20.72 M€ to 37.46 M€ for C6, from 720.97 M€ to 1835.70 M€ for Ctotal, from 138.22 $€ / M W h$ to $1186.30 € / M W h$ for LCOE, from 18 years to 22 years for DPBP, from $-176.90 \%$ to $7.83 \%$ for IRR, and from $-840.31 €$ to $59.06 €$ for NPV.

Regarding case 2, results depends on the location and they go (see Figure 9): from 4.85 M€ to 503.08 M€ for C1; 0.34 M€ for C2; from 367.45 M€ to 676.09 M€ for C3; from 9.92 M€ to 180.32 M€ for C4; from 314.59 M€ to 482.57 M€ for C5; from 20.72 M€ to 37.46 M€ for C6; from 720.97 M€ to 1835.70 M€ for Ctotal; from 138.22 $€ / M W h$ to 1,186.30 $€ / M W h$ for LCOE; from 18 years to 22 years for DPBP; from $-176.90 \%$ to $7.83 \%$ for IRR; and from $-840.31 €$ to $59.06 €$ for NPV.

Regarding Case 4, the results depend on the location, and they go (see Figure 11) from 4.14 M€ to 167.97 M€ for C1, 0.17 M€ for C2, from 222.77 M€ to 350.75 M€ for C3, from 7.37 M€ to 186.64 M€ for $\mathrm{C} 4$, from 355.56 M€ to 521.30 M€ for C5, from 11.60 M€ to 29.81 M€ for C6, from 603.83 M€ to 1210.40 M€ for Ctotal, from 167.85 $€ / M W h$ to $1340.10 € / M W h$ for LCOE, more than 22 years for DPBP, from $-182.39 \%$ to $-3.57 \%$ for IRR, and from $-465.38 €$ to $-39.78 €$ for NPV.

Therefore, considering all of these results, the user can select what is the best technology depending on the location. In this sense, in terms of LCOE, the best technology for the case study is the Case 1 (offshore wind-WindFloat), because it has the smallest LCOE (100.31€/MWh), and the worst technology is Case 3 (wave energy-AquaBuoy), with a minimum value of $756.39 € / \mathrm{MWh}$. On the other hand, in terms of IRR and NPV, the best value is also for Case 1 with $14.75 \%$ and $330.85 €$, respectively, and the worst is Case 3 , with values of $-173.52 \%$ and $-581.42 €$, respectively. 

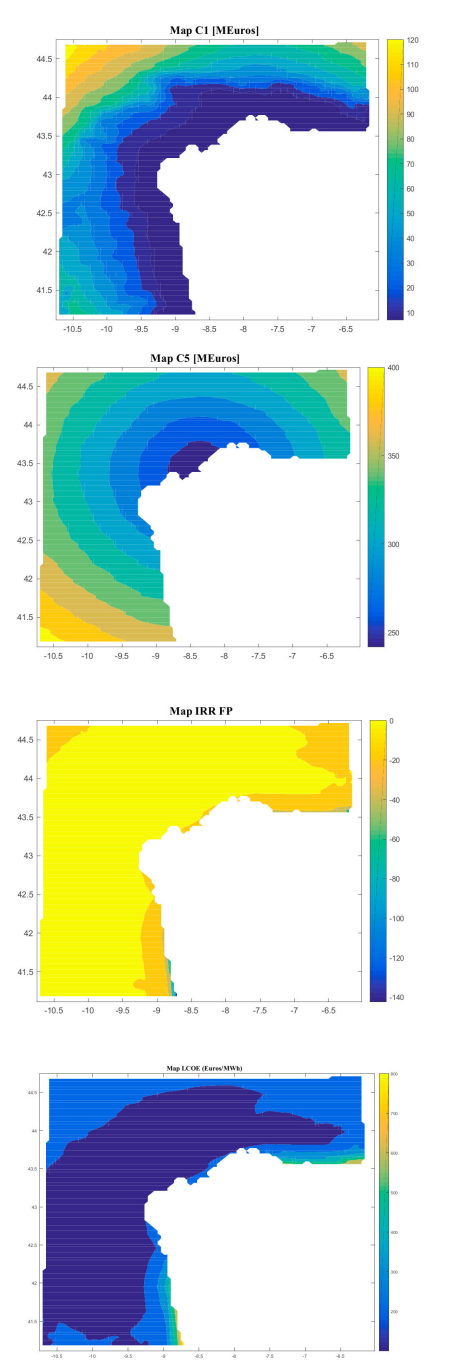

Figure 8. Results (C1, C1, C3, C4, C5, C6, Ctotal, LCOE, DPBP, IRR, NPV) for Case 1.
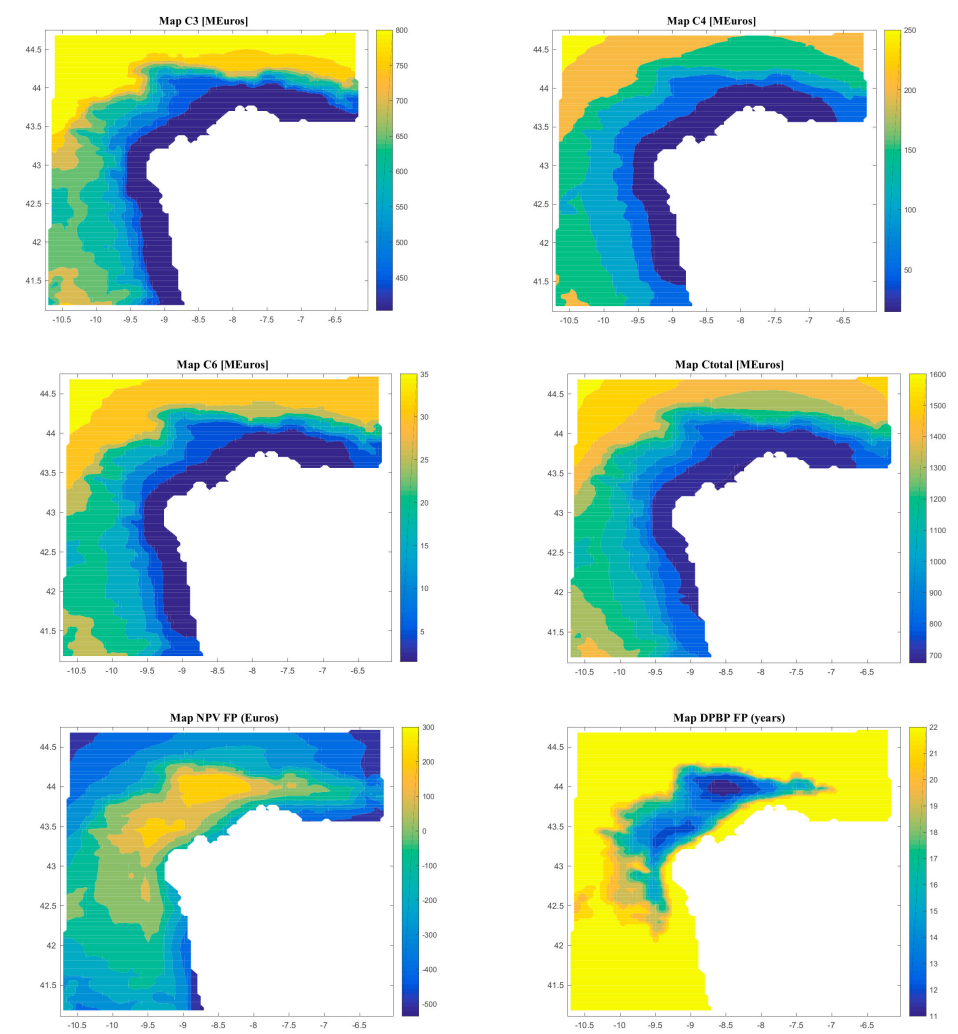


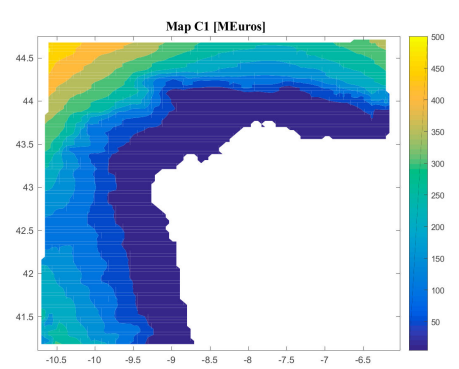

Map C5 [MEuros]
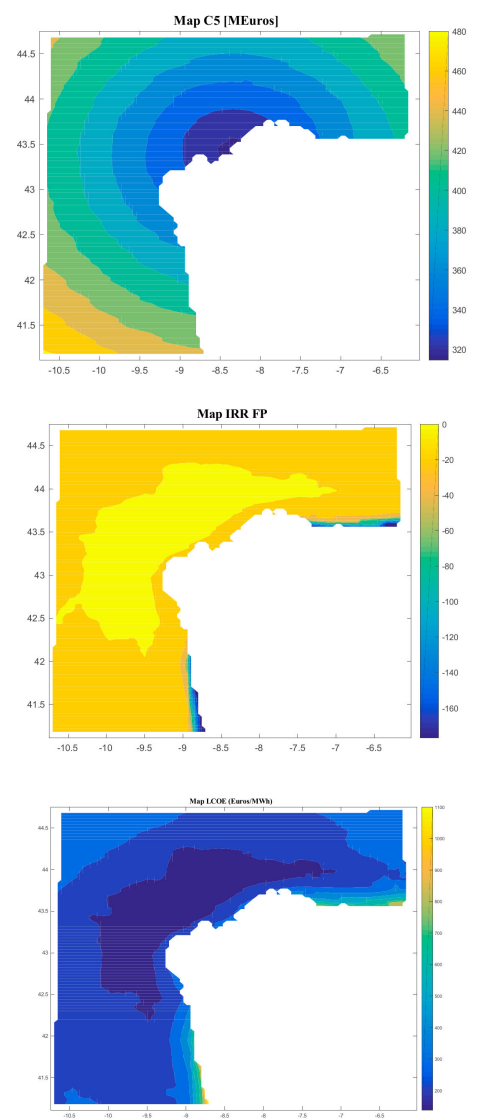

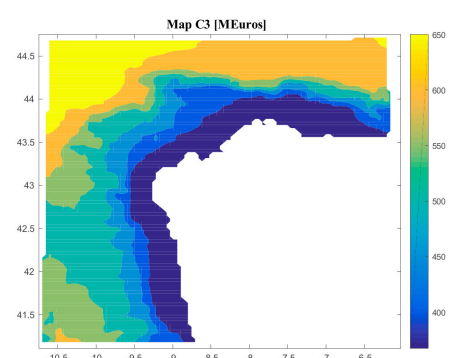

Map C6 [MEuros

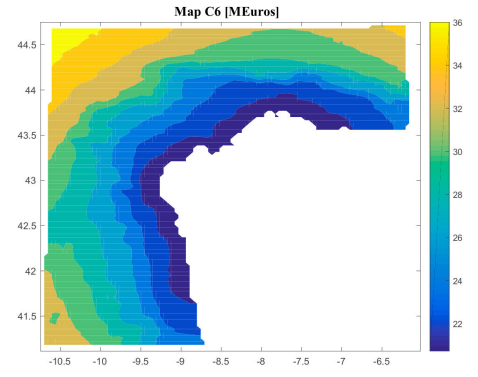

Map NPV FP (Euroe

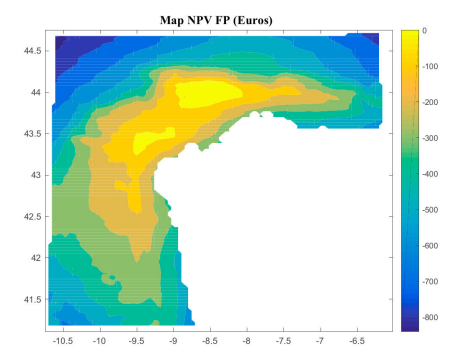

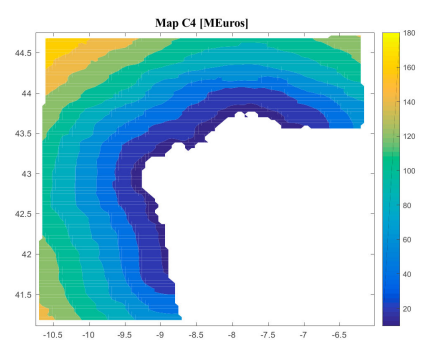
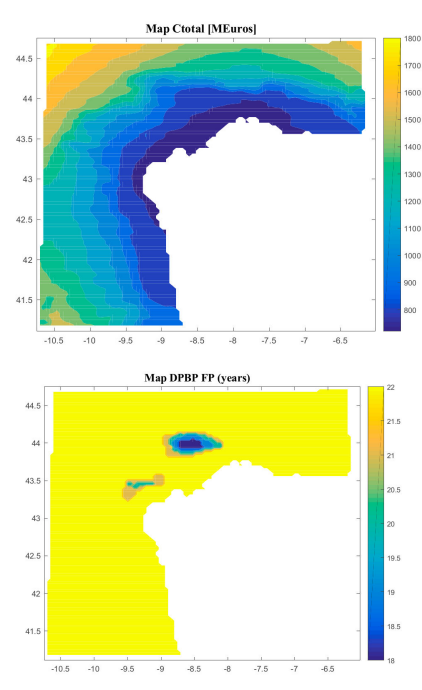

Figure 9. Results (C1, C1, C3, C4, C5, C6, Ctotal, LCOE, DPBP, IRR, NPV) for Case 2. 

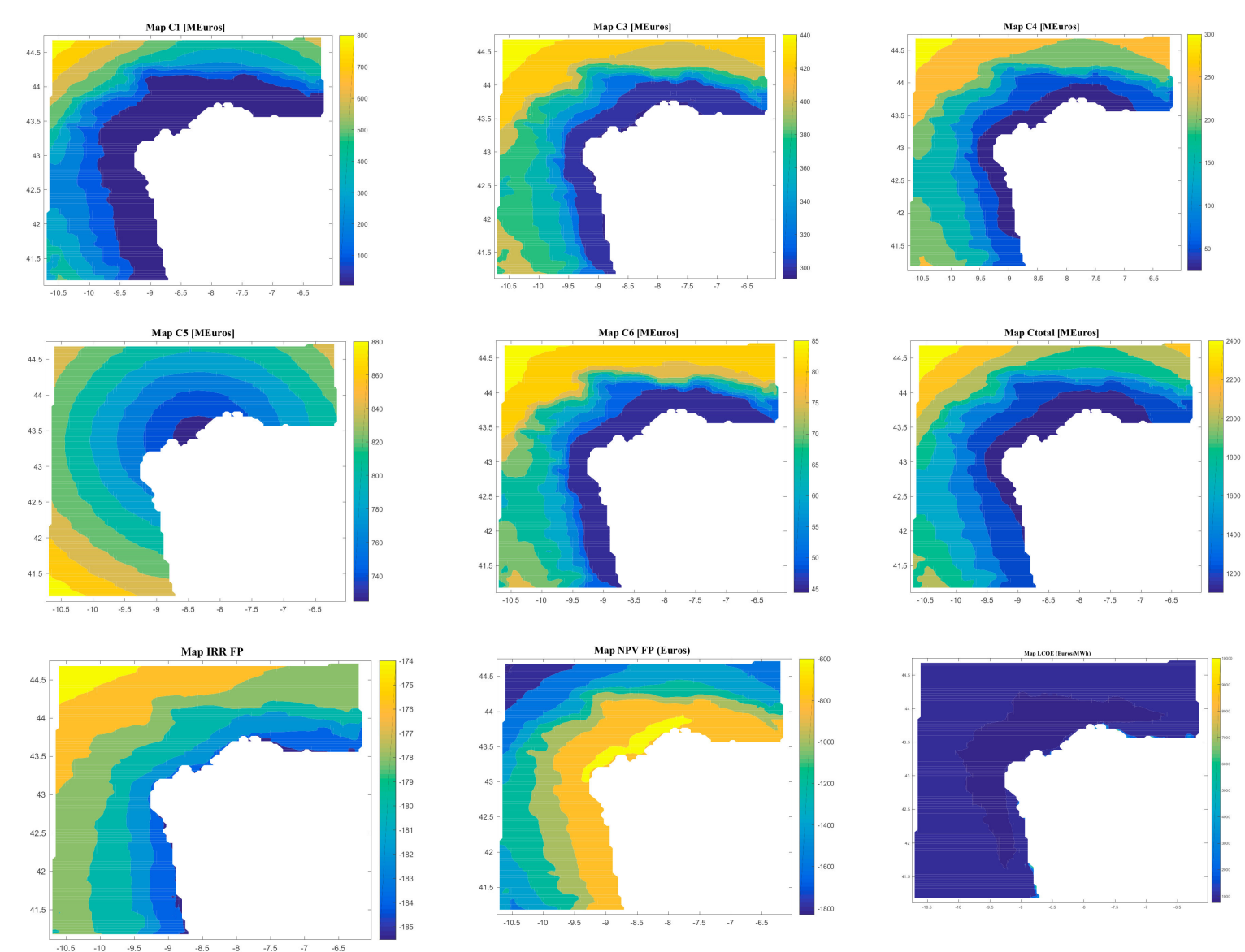

Figure 10. Results (C1, C1, C3, C4, C5, C6, Ctotal, LCOE, DPBP, IRR, NPV) for Case 3. 

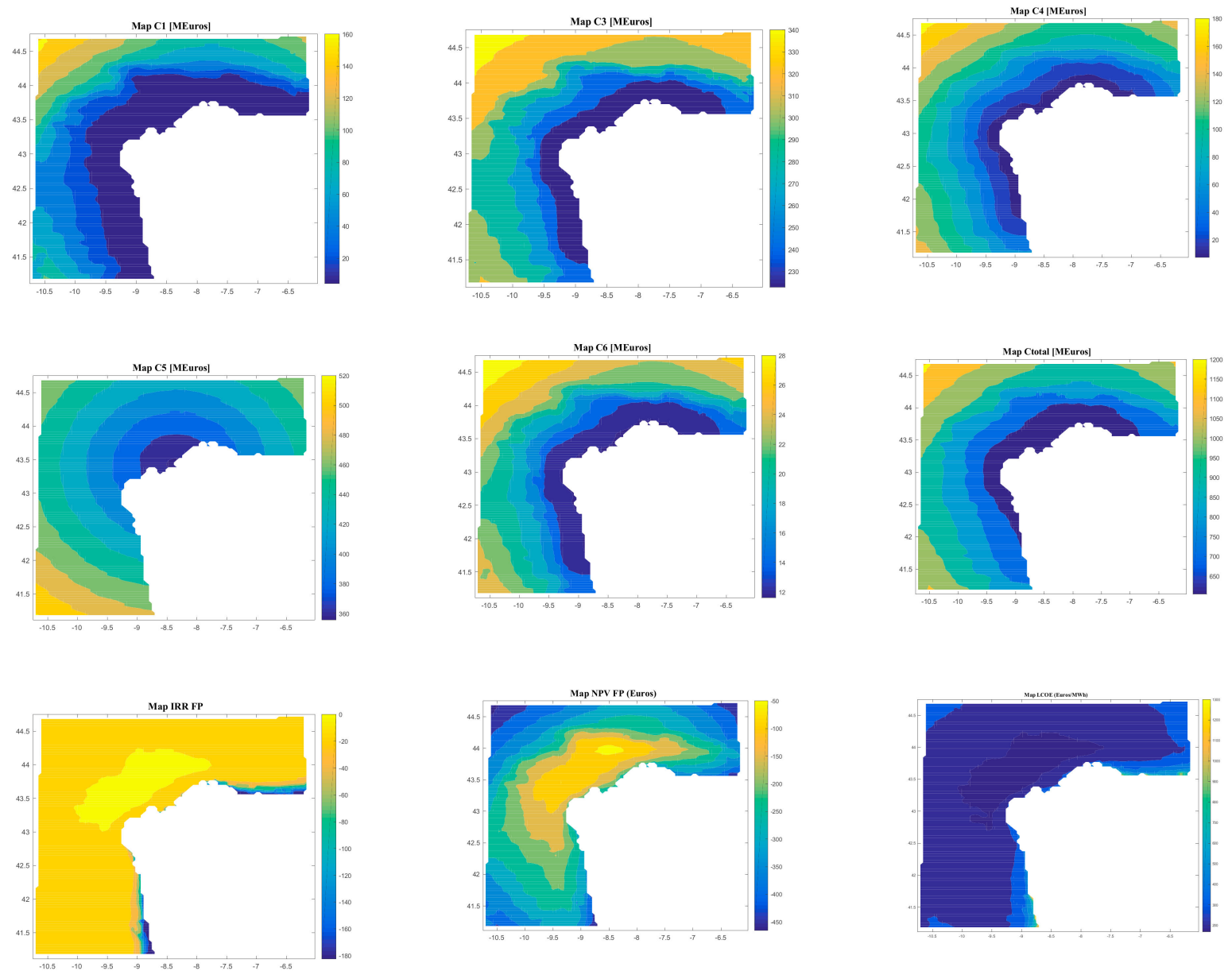

Figure 11. Results (C1, C1, C3, C4, C5, C6, Ctotal, LCOE, DPBP, IRR, NPV) for Case 4. 


\section{Conclusions}

The objective of this work was to present a software to calculate the most important parameters of the feasibility of a floating offshore renewable farm in a selected location. This tool can be valuable for enterprises or public entities that want to know the best places where an offshore renewable energy farm can be located, because this can compile the software for the economic calculation of the most important types of offshore renewable energies existing in the world.

The software can calculate the economic parameters of several types of offshore renewable energies, namely: one renewable energy (floating offshore wind-WindFloat, TLP, and spar; floating wave energy-Pelamis and AquaBuoy), hybrid offshore wind and wave systems (Wave Dragon and W2Power), and combined offshore wind and waves with different systems (independent arrays, peripherally distributed arrays, uniformly distributed arrays, and non-uniformly distributed arrays).

The user can select several inputs, namely: location, configuration of the farm, type of floating offshore platform, type of calculation of the wave's energy, power of the farm, life-cycle of the farm, electric tariff, capital cost, corporate tax, steel cost, percentage of financing, interest, and capacity of the shipyard.

The economic results are as follows: the cost of each phase of the life-cycle of the project, the total cost of the life-cycle of the farm, the internal rate of return (IRR), the net present value (NPV), the discounted payback period (DPBP), and the levelized cost of energy (LCOE).

The case study considered here analysed the Galician region (North-West of Spain), using four alternatives depending on the technology, namely: one renewable energy (offshore wind, WindFloat; wave energy, AquaBuoy; and a hybrid system with offshore wind and waves, W2Power) and two renewable energies installed separately in the same farm (offshore wind, Windfloat and wave energy, AquaBuoy). The software gives the results for the case that the user selects. In this particular case study, the technology that is more economically feasible is the offshore wind (WindFloat) with the best value of LCOE (100.31 €/MWh), IRR (14.75\%, and NPV (330.85€), and the technology with the worst economic values is the wave energy (AquaBuoy), with results of $756.39 € / \mathrm{MWh}$ (LCOE), $-173.52 \%$ of IRR, and $-581.42 €$ of NPV.

The results depend on the shape and scale parameters of the offshore wind resources, the distance from farm to shore, distance from farm to shipyard, distance from farm to port, the height and the period of waves, and the bathymetry of the location of study. The results indicate the economic feasibility of a farm of floating offshore renewable energy in a particular location.

Author Contributions: Introduction: L.C.-S., A.F.-V.; software characteristics: L.C.-S.; case of study and results: L.C.-S.; conclusions: L.C.-S., A.F.-V. All authors have read and agreed to the published version of the manuscript.

Funding: This research received no external funding.

Conflicts of Interest: The authors declare no conflicts of interest.

\section{References}

1. Kallehave, D.; Byrne, B.W.; LeBlanc Thilsted, C.; Mikkelsen, K.K. Optimization of monopiles for offshore wind turbines. Philos. Trans. R. Soc. A Math. Phys. Eng. Sci. 2015, 373, 20140100. [CrossRef] [PubMed]

2. Henderson, A.R.; Witcher, D. Floating offshore wind energy - a review of the current status and an assessment of the prospects. Wind Eng. 2010, 34,1-16. [CrossRef]

3. Wind Europe. Offshore Wind in Europe; Wind Europe: Brussels, Belgium, 2018.

4. Henderson, A.R.; Leutz, R.; Fujii, T. Potential for floating offshore wind energy in japanese waters. In Proceedings of the 12th International Offshore and Polar Engineering Conference, Kitakyushu, Japan, 26-31 May 2002; International Society of Offshore and Polar Engineers: Mountain View, CA, USA, 2002; Volume 3, pp. 505-512.

5. Kosugi, A.; Ogata, R.; Kagemoto, H.; Akutsu, Y.; Kinoshita, T. A feasibility study on a floating wind farm off Japan coast. In Proceedings of the 12th 2002 International Offshore and Polar Engineering Conference, Kitakyushu, Japan, 26-31 May 2002. 
6. Ulazia, A.; Gonzalez-Roji, S.J.; Ibarra-Berastegi, G.; Carreno-Madinabeitia, S.; Saenz, J.; Nafarrate, A. Seasonal Air Density Variations over the East of Scotland and the Consequences for Offshore Wind Energy. In Proceedings of the 7th International IEEE Conference on Renewable Energy Research and Applications (ICRERA 2018), Paris, France, 14-17 October 2018; Volume 5, pp. 261-265.

7. Myhr, A.; Bjerkseter, C.; Ågotnes, A.; Nygaard, T.A. Levelised cost of energy for offshore floating wind turbines in a lifecycle perspective. Renew. Energy 2014, 66, 714-728. [CrossRef]

8. Repsol Repsol. Available online: http://www.repsol.es (accessed on 26 December 2019).

9. Navantia Navantia. Available online: http://www.navantia.es (accessed on 26 December 2019).

10. Schillings, C.; Wanderer, T.; Cameron, L.; van der Wal, J.T.; Jacquemin, J.; Veum, K. A decision support system for assessing offshore wind energy potential in the North Sea. Energy Policy 2012, 49, 541-551. [CrossRef]

11. Castro-Santos, L.; Prado Garcia, G.; Estanqueiro, A.; Justino, P.A.P.S. The Levelized Cost of Energy (LCOE) of wave energy using GIS based analysis: The case study of Portugal. Int. J. Electr. Power Energy Syst. 2015, 65, 21-25. [CrossRef]

12. Itiki, R.; Di Santo, S.G.; Costa, E.C.M.; Monaro, R.M. Methodology for mapping operational zones of VSC-HVDC transmission system on offshore ports. Int. J. Electr. Power Energy Syst. 2017, 93, 266-275. [CrossRef]

13. Castro-Santos, L.; Filgueira-Vizoso, A.; Lamas-Galdo, I.; Carral-Couce, L. Methodology to calculate the installation costs of offshore wind farms located in deep waters. J. Clean. Prod. 2018, 170, 1124-1135. [CrossRef]

14. Aubault, A.; Cermelli, C.; Roddier, D. Windfloat: a floating foundation for offshore wind turbines. Part III: Structural analysis. In Proceedings of the 28th ASME International Conference on Ocean, offshore and Arctic Engineering (OMAE 2009), Honolulu, HI, USA, 31 May-5 June 2009; pp. 1-8.

15. Maciel, J. The WindFloat Project; EDP: Lisbon, Portugal, 2010.

16. Matha, D. Model Development and Loads Analysis of an Offshore Wind Turbine on a Tension Leg Platform with a Comparison to Other Floating Turbine Concepts; National Renewable Energy Laboratory (NREL): Golden, CO, USA, 2010.

17. Oguz, E.; Clelland, D.; Day, A.H.; Incecik, A.; López, J.A.; Sánchez, G.; Almeria, G.G. Experimental and numerical analysis of a TLP floating offshore wind turbine. Ocean Eng. 2018, 147, 591-605. [CrossRef]

18. Driscoll, F.; Jonkman, J.; Robertson, A.; Sirnivas, S.; Skaare, B.; Nielsen, F.G. Validation of a FAST Model of the Statoil-hywind Demo Floating Wind Turbine. Energy Procedia 2016, 94, 3-19. [CrossRef]

19. Athanasia, A. Deep offshore and new foundation concepts. In DeepWind2013; DeepWind: Trondheim, Norway, 2013; p. 17.

20. Jonkman, J.; Matha, D. Dynamics of offshore floating wind turbines — analysis of three concepts. Wind Energy 2011, 14, 557-569. [CrossRef]

21. Jonkman, J.; Matha, D. A Quantitative Comparison of the Responses of Three Floating Platforms; National Renewable Energy Laboratory (NREL): Stockholm, Sweden, 2010.

22. Sclavounos, P.D.; Lee, S.; DiPietro, J. Floating offshore wind turbines: Tension leg platform and taught leg buoy concepts supporting 3-5 mw wind turbines. In Proceedings of the European Wind Energy Conference (EWEC), Warsaw, Poland, 20-23 April 2010; pp. 1-7.

23. Collu, M.; Kolios, A.A.J.; Chabardehi, A.; Brennan, F. Marine Renewable and Offshore Wind Energy; RINA-Royal Institution of Naval Architects: London, UK, 2010; pp. 63-74.

24. Wind Europe. Driving Cost Reductions in Offshore Wind. Available online: https://windeurope.org/aboutwind/reports/driving-cost-reductions-offshore-wind/ (accessed on 27 November 2017).

25. Pelamis Wave Power Pelamis. Available online: http://www.pelamiswave.com (accessed on 26 December 2019).

26. Weinstein, A.; Fredrikson, G.; Jane, M.; Group, P.; Denmark, K.N.R. AquaBuOY-The Offshore Wave Energy Converter Numerical Modeling and Optimization; IEEE: Piscataway, NJ, USA, 2003; pp. 1854-1859.

27. Castro-Santos, L.; Silva, D.; Bento, A.R.; Salvação, N.; Soares, C.G. Economic feasibility ofwave energy farms in Portugal. Energies 2018, 11, 1-16. [CrossRef]

28. Pelagic Power AS W2Power. Available online: http://www.pelagicpower.no/ (accessed on 17 December 2016).

29. Castro-Santos, L.; Martins, E.; Soares, C.G. Methodology to calculate the costs of a floating offshore renewable energy farm. Energies 2016, 9, 324. [CrossRef]

30. Castro-Santos, L.; Filgueira-Vizoso, A.; Carral-Couce, L.; Formoso, J.Á.F. Economic feasibility of floating offshore wind farms. Energy 2016, 112, 868-882. [CrossRef] 
31. Castro-Santos, L.; Diaz-Casas, V. Life-cycle cost analysis of floating offshore wind farms. Renew. Energy 2014, 66, 41-48.

32. Dunnett, D.; Wallace, J.S. Electricity generation from wave power in Canada. Renew. Energy 2009, 34, $179-195$. [CrossRef]

33. Page, W.D.W. Wave Dragon Technology. Available online: http://www.wavedragon.net (accessed on 7 September 2016).

34. Floating Power Plant AS Poseidon Floating Power. Available online: http://www.floatingpowerplant.com/ (accessed on 17 February 2016).

35. Castro-Santos, L.; Martins, E.; Guedes Soares, C. Economic comparison of technological alternatives to harness offshore wind and wave energies. Energy 2017, 140, 1121-1130. [CrossRef]

36. Silva, D.; Bento, A.R.; Martinho, P.; Guedes Soares, C. High Resolution local wave energy modelling in the Iberian Peninsula. Energy 2015, 91, 1099-1112. [CrossRef]

37. Silva, D.; Rusu, E.; Guedes Soares, C. Evaluation of Various Technologies for Wave Energy Conversion in the Portuguese Nearshore. Energies 2013, 6, 1344-1364. [CrossRef]

38. Castro-Santos, L.; Martins, E.; Guedes Soares, C. Cost assessment methodology for hybrid floating offshore renewable energy platforms. Renew. Energy 2016, 97, 866-880. [CrossRef]

39. Roddier, D.; Cermelli, C. Windfloat: A floating foundation for offshore wind turbines. Part I: Design basis and qualification process. In Proceedings of the 28th ASME International Conference on Ocean, Offshore and Arctic Engineering (OMAE 2009), Honolulu, HI, USA, 31 May-5 June 2009; pp. 1-9.

(C) 2019 by the authors. Licensee MDPI, Basel, Switzerland. This article is an open access article distributed under the terms and conditions of the Creative Commons Attribution (CC BY) license (http://creativecommons.org/licenses/by/4.0/). 